\title{
Small Area Estimation Jumlah Penderita Penyakit TBC di Kabupaten Lombok Timur Menggunakan Metode Empirical Bayes
}

\author{
Muslimatun Toyyibah $^{a, *}$, Desy Komalasari ${ }^{b}$, Nurul Fitriyani $^{c}$ \\ ${ }^{a}$ Program Studi Matematika, FMIPA, Universitas Mataram, Jl. Majapahit No. 62, Mataram,83125, Indonesia. Email: \\ muslimah94@yahoo.com \\ ${ }^{b}$ Program Studi Matematika, FMIPA, Universitas Mataram, Jl. Majapahit No. 62, Mataram,83125, Indonesia. Email: \\ desykomalasari@unram.ac.id \\ ${ }^{c}$ Program Studi Matematika, FMIPA, Universitas Mataram, Jl. Majapahit No. 62, Mataram,83125, Indonesia. Email: \\ nurul.fitriyani@unram.ac.id
}

\section{A B S T R A C T}

Empirical Bayes is one of small area estimation method that can be used to predict small area parameters. The small area is defined as a subpopulation of small sample sizes. Empirical Bayes is suitable for use in counted data with Poisson-Gamma model. The purpose of this research was to determine the sub-districts that have the highest risk in the number of people with TBC disease in East Lombok Regency. Based on the results, the analysis showed that sub-districts with the highest risk were Sukamulia Sub-district with 1.65543 value of relative risk in 2014, Sambelia Sub-district with 1.80396 value of relative risk in 2015, and Sambelia Sub-district with 4.12718 values ov relative risk in 2016.

Keywords: Empirical Bayes, Poisson-Gamma Model, Relative Risk.

\section{Pendahuluan}

Small Area Estimation (SAE) merupakan suatu teknik statistik untuk menduga parameter pada suatu wilayah dengan ukuran sampelkecil. Salah satu penerapan SAE untuk data cacahan adalah pada penyebaran penyakit. Metode yang cocok untuk data cacahan adalah metode empirical Bayes. Kelebihan metode inidibandingkan dengan metode hirarchical Bayes, yaitu lebih mudah dalam pendugaan parameter. Selain itu, metode empirical Bayes mampu menampung informasi antar area, atau dengan kata lain dapat mereduksi jumlah kuadrat tengah galat (mean square error) dan menghasilkan penduga resiko relatif yang lebih baik (Rao, 2003).

Penduga resiko relatif sederhana adalah standardized mortality ratio (SMR) sebagai penduga langsung, yang diperoleh dari asumsi bahwa banyaknya pengamatan suatu kasus menyebar Poisson, hal ini dikarenakan jumlah penderita penyakit merupakan variabel respon dimana variabel respon tersebut merupakan data hitung dan peluang terjadinya kasus penyakit sangat kecil. Pada distribusi Poisson terdapat asumsi bahwa dalam variabel respon harus terjadi equidispersi (rataan sama dengan varian), namun yang sering terjadi adalah variabel respon mengalami overdispersi (rataan lebih kecil dari varian). Overdispersi ini juga lebih sering terjadi pada kondisi data yang dikumpulkan dari area-area dengan varian yang berbeda khususnya dari luas area, jumlah penduduknya, serta berbagai faktor lainnya. Oleh karenanya, distribusi ini kurang tepat digunakan karena dapat menghasilkan simpangan baku yang bias.

Masalah overdispersi dapat diatasi dengan menggunakan pendekatan model Poisson-Gamma. Model ini telah dikenal luas untuk menangani pengaruh acak dengan overdispersi secara lebih baik dibandingkan

*Corresponding author.muslimah94@yahoo.com 
pendekatan/ distribusi lain (Hadi dan Notodiputro, 2008). Pendekatan/ distribusi lain tersebut diantaranya Poisson Lognormal dan Poisson Mixture Model. Pada penelitian, digunakan metode empirical Bayes dengan model PoissonGamma untuk menduga penderita TBC di Kabupaten Lombok Timur.

\section{Small Area Estimation (SAE)}

SAE merupakan suatu teknik statistik yang digunakan untuk menduga parameter-parameter area kecil. Secara esensial, terdapat dua tipe model pada SAE, yakni model berbasis area level dan model berbasis unit level. Pada model area kecil berbasis area, data pendukung yang tersedia hanya sampai level area. Model level area menghubungkan penduga langsung area kecil dengan data pendukung dari domain lain untuk setiap area. Parameter area kecil yang ingin diamati adalah $\theta_{i}$. Model linear yang menjelaskan hubungan tersebut adalah (Rao, 2003):

$$
\theta_{i}=x_{i}^{T} \beta+z_{i} v_{i} \quad, i=1,2, \cdots m
$$

Dalam membuat kesimpulan tentang populasi, diasumsikan bahwa nilai penduga langsung $\hat{\theta}_{i}$ diketahui maka dapat dinyatakan sebagai berikut.

$$
\widehat{\theta}_{i}=\theta_{i}+e_{i}
$$

dengan $e_{i}$ merupakan samplingerror yang berdistribusi normal.

Model area kecil untuk level area terdiri dari dua tingkat komponen model yaitu, komponen model penduga tidak langsung sesuai dengan persamaan (2.1) dan model penduga langsung sesuai dengan persamaan (2.2). Model pada persamaan (2.1) dan (2.2) jika digabungkan membentuk persamaan sebagai berikut.

$$
\widehat{\theta}_{i}=x_{i}^{T} \beta+z_{i} v_{i}+e_{i} \quad, i=1,2, \cdots m
$$

\section{Standardized Mortality Ratio (SMR)}

SMR merupakan penduga langsung yang paling sederhana untuk resiko relatif pada penyebaran penyakit pada SAE (Rao, 2003). SMR berguna dalam mengetahui sebaran geografis suatu penyakit. SMR ini diperoleh dari asumsi umum penyebaran penyakit bahwa banyaknya pengamatan suatu kasus yaitu, $y_{i} \mid \theta_{i} \sim \operatorname{Poisson}\left(e_{i} \theta_{i}\right)$, dengan $e_{i}$ adalah nilai harapan banyaknya suatu kasus pada area $\mathrm{ke}-i$ dan $\theta_{i}$ adalah resiko relatif area $\mathrm{ke}-i$ yang tidak diketahui.

$$
e_{i}=n_{i}\left(\sum_{i=1}^{m} y_{i} / \sum_{i=1}^{m} n_{i}\right)
$$

dengan,

$y_{i}=$ jumlah pengamatan (penderita) penyakit TBC pada pada kecamatan ke $-i$.

$n_{i}=$ banyaknya penduduk pada kecamatan ke $-i$.

$m=$ jumlah kecamatan.

Selanjutnya, dengan memaksimumkan fungsi peluangnya diperoleh penduga SMR, sebagai berikut.

$$
\hat{\theta}_{i}=\frac{y_{i}}{e_{i}}
$$

\section{Metode Empirical Bayes}

Metode empirical Bayes merupakan metode yang cocok digunakan dalam menangani data biner dan data cacahan pada SAE. Secara ringkas, metode empirical Bayes pada SAE (Rao, 2003):

1. Mendapatkan fungsi kepadatan peluang akhir (posterior) dari parameter area kecil yang menjadi perhatian;

2. Menduga parameter model dari fungsi kepadatan peluang marginal; dan

3. Menggunakan fungsi kepekatan peluang posterior dugaan untuk membuat inferensi parameter area kecil yang menjadi perhatian.

\section{Model Poisson-Gamma}

Dalam model Poisson-Gamma diperoleh dua tahap yaitu pertama, diasumsikan bahwa $y_{i} \mid \theta_{i} \sim \operatorname{Poisson}\left(e_{i} \theta_{i}\right)$. Tahap kedua diasumsikan bahwa $\theta_{i} \sim \operatorname{Gamma}(\beta, \alpha)$ dimana sebagai prior dengan rata-rata $\beta / \alpha$ dan varian $\beta / \alpha^{2}$ maka diperoleh (Rao, 2003).

$$
f\left(y_{i}, \theta_{i}\right)=\frac{\alpha^{\alpha}}{\Gamma(\alpha)} e^{-\alpha \theta_{i}} \theta_{i}^{\beta-1}, y_{i}=0,1, \ldots, \theta_{i}>0
$$

dan 


$$
E\left(\theta_{i}\right)=\frac{\beta}{\alpha}=\mu, \quad V\left(\theta_{i}\right)=\frac{\beta}{\alpha^{2}}
$$

dengancatatan bahwa:

$$
\theta_{i} \mid y_{i}, \alpha, \beta \sim \operatorname{Gamma}\left(y_{i}+\beta, e_{i}+\alpha\right) \text {. }
$$

Berikut ini merupakan penduga bayes bagi $\theta_{i}$ dan varian posterior bagi $\theta_{i}$ diperoleh dari persamaan (2.7) dengan mengganti $\alpha$ ke $e_{i}+\alpha$ dan $\beta$ ke $y_{i}+\alpha$ adalah sebagai berikut.

$$
\hat{\theta}_{i}^{B}(\beta, \alpha)=E\left(\theta_{i} \mid y_{i}, \beta, \alpha\right)=\frac{\left(y_{i}+\beta\right)}{\left(e_{i}+\alpha\right)}
$$

dan

$$
V\left(\theta_{i} \mid y_{i}, \beta, \alpha\right)=g_{1 i}\left(y_{i}, \beta, \alpha\right)=\frac{\left(y_{i}+\beta\right)}{\left(e_{i}+\alpha\right)^{2}}
$$

Selanjutnya, penduga empirical Bayes bagi $\theta_{i}$ adalah sebagai berikut.

$$
\widehat{\theta}_{i}^{E B}=\widehat{\gamma}_{i} \widehat{\theta}_{i}+\left(1-\widehat{\gamma}_{i}\right) \widehat{\mu}_{i}
$$

dengan,

$$
\hat{\gamma}_{i}=\frac{e_{i}}{\left(e_{i}+\hat{\alpha}\right)} .
$$

\section{Metodologi}

Jenis data yang digunakan dalam penelitian ini data kuantitatif. Data kuantitatif adalah data yang bias dihitung atau diukur dengan angka. Data yang digunakan adalah data sekunder, yaitu data yang diperoleh dari Dinas Kesehatan Kabupaten Lombok Timur Tahun 2014-2016, mengenai penyakit TBC untuk seluruh kecamatan yang ada di Kabupaten Lombok Timur, dimana data penyakit TBC yang digunakan adalah data suspect TBC.

Langkah-langkah Small Area Estimation jumlah penderita penyakit TBC di Kabupaten Lombok Timur menggunakan metode empirical Bayesantara lain sebagai berikut.

1. Pendugaan langsung menggunakan metode Standaridized Mortality ratio (SMR). (a) Ditentukan $e_{i}$ sebagai nilai harapan banyaknya suatu kasus pada kecamatan ke-idengan rumus pada persamaan (2.4).

(b) Ditentukan penduga SMR untuk semua kecamatan di Kabupaten Lombok Timur menggunakan rumus pada persamaan (2.5).

2. Pendugaan tidak langsung menggunakan metode empirical Bayes dengan model Poisson-Gamma.

(a) Ditentukan parameter $\hat{\beta}$ dan $\hat{\alpha}$ untuk semua kecamatan di Kabupaten Lombok Timur.

(b) Ditentukan $\hat{\mu}_{i}$ sebagai nilai harapan resiko relatif ke $-i$ untuk semua kecamatan di Kabupaten Lombok Timur.

(c) Ditentukan penduga empirical Baye suntuk semua kecamatan di Kabupaten Lombok Timur.

(d) Menarikkesimpulan, ditunjukkan hasil SAE menggunakan metode empirical Bayes dengan model Poisson-Gamma.

\section{Hasil dan Pembahasan}

Untuk menentukan penduga langsung, terlebih dahulu ditentukan nilai harapan banyak suatu kasus pada area ke $-i$ dengan rumus pada persamaan (2.5). Pendugaan langsung digunakan untuk menentukan penduga tidak langsung menggunakan metode penduga empirical Bayes dengan model Poisson-Gamma. Terlebih dahulu dilakukan pendugaan parameter prior menggunakan persamaan berikut.

$$
\widehat{\alpha}=\frac{m_{1}^{\prime}}{\left(m_{2}^{\prime}-m_{1}^{\prime 2}-m_{1}^{\prime}\right)} e_{i}
$$

dan

$$
\hat{\beta}=\frac{\left(\frac{\sum_{i=1} y_{i}}{n}\right)^{2}}{\left[\left(\frac{\sum_{i=1} y_{i}^{2}}{n}\right)-\left(\frac{\sum_{i=1} y_{i}}{n}\right)^{2}-\left(\frac{\sum_{i=1} y_{i}}{n}\right)\right]}
$$

Setelah penduga parameter ditentukan, untuk Kecamatan Keruak, maka diperoleh nilai harapan resiko relatif sesuai dengan persamaanberikut.

$$
E\left(\theta_{i}\right)=\frac{\beta}{\alpha}=\mu, \quad V\left(\theta_{i}\right)=\frac{\beta}{\alpha^{2}}
$$


Nilai pendugaan tidak langsung kemudian ditentukan dengan menggunakan rumus pada persamaan (2.10). PadaTabel 1 berikut diberikan rekapitulasi penduga tidak langsung menggunakan metode empirical Bayes dengan model Poisson-Gamma.

Tabel 1 - Penduga Empirical Bayes dengan Model Poisson-Gamma

\begin{tabular}{lccc}
\hline & \multicolumn{3}{c}{$\hat{\theta}_{i}^{E B}$ selama 3 Tahun } \\
\cline { 2 - 4 } Kecamatan & $\mathbf{2 0 1 4}$ & $\mathbf{2 0 1 5}$ & $\mathbf{2 0 1 6}$ \\
\hline Keruak & 0.9954737 & 1.4127939 & 0.8846023 \\
Jerowaru & 0.9929200 & 0.9621239 & 1.1543840 \\
Sakra & 0.9993889 & 0.8985118 & 0.5768881 \\
Sakra Barat & 0.9983689 & 0.6708415 & 0.9997575 \\
Sakra Timur & 0.9989338 & 0.7030272 & 0.9147953 \\
Terara & 1.0161701 & 0.5540724 & 0.4398388 \\
Montong Gading & 0.9840695 & 0.8397881 & 1.2754160 \\
Sikur & 1.0065076 & 1.6749178 & 1.0303371 \\
Masbagik & 1.0019871 & 1.0787080 & 0.7258210 \\
Pringgasela & 0.6071306 & 0.7066346 & 0.7672614 \\
Sukamulia & $\mathbf{1 . 6 5 5 3 9 5 2}$ & 1.1362765 & 1.3452365 \\
Suralaga & 0.9919731 & 1.0101698 & 0.4165939 \\
Selong & 0.9906570 & 0.7506417 & 1.1139285 \\
Labuan Haji & 1.0023728 & 0.9935568 & 1.7153684 \\
Pringgabaya & 1.0043125 & 1.2315533 & 1.1047603 \\
Suela & 0.9987475 & 0.6586192 & 0.5096292 \\
Aikmel & 1.0014671 & 1.0865984 & 0.9367257 \\
Wanasaba & 1.0069112 & 1.0027910 & 0.6349075 \\
Sembalun & 1.0035711 & 0.3366547 & 0.8919953 \\
\hline
\end{tabular}

\begin{tabular}{lccc}
\hline \multirow{2}{*}{ Kecamatan } & \multicolumn{3}{c}{$\hat{\theta}_{i}^{E B}$ selama 3 Tahun } \\
\cline { 2 - 4 } & $\mathbf{2 0 1 4}$ & $\mathbf{2 0 1 5}$ & $\mathbf{2 0 1 6}$ \\
\hline Sambelia & 0.9939504 & $\mathbf{1 . 8 0 1 4 7 9 6}$ & $\mathbf{4 . 1 2 7 1 8 1 9}$ \\
\hline
\end{tabular}

Tabel 4.1 menunjukkan nilai resiko relatif setiap kecamatan selama tahun 2014-2016 di Kabupaten Lombok Timur. Hasil perhitungan pada Tabel 4.1 menunjukkan selama tahun 2014-2016, terdapat 9 kecamatan yang memiliki resiko tinggi, dengan Kecamatan Sukamulia merupakan kecamatan dengan resiko tertinggi dengan resiko relatif sebesar 1.6553952 pada tahun 2014, Kecamatan Sambelia dengan resiko tertinggi dengan resiko relatif sebesar 1.8014796 pada tahun 2015, dan Kecamatan Sambelia merupakan kecamatan yang tertinggi dengan resiko relatif sebesar 1.6983743 pada tahun 2016.

\section{Kesimpulan}

Kebutuhan informasi yang reliabel mengenai kecamatan dengan resiko tertinggi terjangkit suatu penyakit menjadi keharusan. Informasi ini akan dijadikan rujukan bagi pemerintah melalui dinas kesehatan dalam upaya menanggulangi penyebaran penyakit di Kabupaten Lombok Timur khususnya.

\section{DAFTAR PUSTAKA}

Rao, J.N.K.(2003).Small Area Estimation, Canada: John Wiley \&Sons Inc.

Hadi, F. A., Nusyirwan., dan Notodiputro, K. A. (2008). Penduga Maksimum Likelihood untuk Parameter Dispersi Model Poisson-Gamma dalam Konteks Pendugaan Area Kecil, Seminar Nasional Matematika dan Pendidikan Matematika. 